7. Teacher Education in Europe An ETUCE Policy Paper. Adopted by the Executive Board on 14th April 2008 // Editor responsible at law: Martin Romer. - Published by the European Trade Union Committee for Education - Brussels, 2008. - 64 P.

8. Language policy | Fact sheets on the European Union URL: chttp://www.europarl.europa.eu/ factsheets/en/sheet/142/language-policy

9. Yaschuk I.P, Binyts'ka K.M, Kuz'ma I.I. Porivnial'nyj analiz profesijnoi pidhotovky majbutnikh uchyteliv pochatkovoi osvity v Rumunii ta Uhorschyni. / Yaschuk I.P., Binyts'ka K.M., Kuz'ma I.I.// nauk.-prakt. zhurnal Nauka i Pedahohika -2018. Vypusk - 2. S. 153-160.

Одержано статтю: 3.03 .2019

Прийнято до друку: 27.03.2019

УДК 37:364.65

DOI: $10.15330 /$ esu. $15.38-45$

\section{Ільдіко Орос,}

кандидат педагогічних наук,

Закарпатський угорський інститут

ім. Ференца Ракоці II (м. Берегово, Україна)

Ildiko Oros,

Candidate of pedagogical sciences,

Ferenc Rakoczi II Transcarpathian Hungarian

Institute (Beregovo, Ukraine)

ildiko@kmf.uz.ua

\title{
КОНЦЕПТУАЛЬНІ ПЦДХОДИ ДО ОСВІТИ ДОРОСЛИХ В УКРАЇНІ
}

\section{CONCEPTUAL APPROACHES TO ADULT EDUCATION IN UKRAINE}

Освіту дорослих розглядають як систему, покликану компенсувати недоліки загальноосвітньої і вищої иколи.

В Украӥні останнім часом видана низка кончепчій, у яких визначено основні завдання та мета розвитку освіти дорослих, приниипи, форми освіти, напрями реалізачіі кончепчії, передбачено й очікувані результати, піднімається питання обміну досвідом із різиими країнами щодо розвитку освіти дорослих; визначено чинники, які впливають на розвиток професійної освіти у XXI столітті, яка повинна задовольняти потреби держави у кваліфікованих кадрах і потреби особистості в якісній профосвіті.

3'ясовано зміст кончептуальних положень формування освітньої системи дорослих України та яку роль відіграють конџетиї у розвитку освіти дорослих в Украйні.

Ключові слова: концептуальні положення, освіта дорослих, Украйна, потреби держави, кваліфіковані кадри, освітня система дорослих.

Recently, a number of concepts have been published in Ukraine, in which the main tasks and goals of adult education development, principles, forms of education, directions of the concept implementation, anticipated and expected results are determined, the issue of the exchange of experience with different countries on the development of adult education is raised; The factors influencing the development of vocational education in the XXI century, which should meet the needs of the state in skilled personnel and the needs of the person in high-quality professional education, are determined.

In 2002, the concept of postgraduate education was approved by the Board of MES of Ukraine. In order to implement the national strategy for the development of education in Ukraine for the period up to 2021 the concept of the development of continuous pedagogical education was adopted, which defined the basic principles of the development of continuous pedagogical education (continuity, the combination of national educational traditions and best world experience, flexibility of response to social changes and predictability, innovation), the task of its development (improvement of the structure of postgraduate education, the direction of the development of continuous pedagogical education for modernization on all levels of education content, forms, methods and learning technologies as required informational civil 
multicultural society); quality assurance of education; introduction of European vocational and pedagogical experience in the development of continuous pedagogical education. An important point was the publication of the concept of adult education in Ukraine in 2011, developed by L. Lukyanova. The project of the concept of the development of Ukraine's education for the period 2015-2025 is the creation of favorable conditions for mobility. Significant role in the development of vocational education is played by the Concept of development of vocational (vocational) education in Ukraine. The use of the concept of open learning improves the effectiveness of learning, provides the opportunity to work with a large number of adult learners.

The article clarifies the content of the conceptual provisions for the formation of the educational system of adults in Ukraine and the role played by the concepts in the development of adult education in Ukraine.

Key words: conceptual provisions, adult education, Ukraine, needs of the state, skilled personnel, educational system of adults.

Постановка проблеми у загальному вигляді та її зв'язок із важливими науковими чи практичними завданнями. Важливого значення в контексті сучасних процесів глобалізації, інтеграції та інформатизації суспільства набуває освіта дорослих. Її нова роль визначається піднесенням iї суспільної значущості і цінності, змінами в умовах діяльності людей упродовж життя, а також певними віковими, психологічними, соціальними особливостями дорослих. Оскільки освіта дорослих - це пролонгований процес життєвого розвитку людини, що відбувається впродовж усього життя, швидкоплинність змін у сучасному суспільстві об'єктивно зумовило необхідність формування особистості, здатної до адекватного сприйняття i творення таких змін як природної норми. Водночас, адаптація до цих змін неможлива без задоволення освітніх потреб людини впродовж життя.

Освіта дорослих - невід'ємна і водночас відособлена частина системи освіти. Комплекс проблем, пов'язаних 3 іi функціонуванням i розвитком, має свою змістову специфіку, зумовлену особливостями контингенту, що навчається, а також своєрідністю завдань. Звідси специфіка теоретичних підходів до питань стратегії розвитку освіти в сучасних умовах [1, с. 5-6].

Аналіз останніх досліджень i публікацій, в яких започатковано розв'язання порушеної проблеми і на які спирається автор. Цією проблемою займаються вчені:. Архипова, С. Змєйов, Н. Кулюткін, Л. Лук'янова, Н. Ничкало, В. Подобед, Д. Титаренко, І. Фольварочний та ін.

Виокремлення невирішених раніше аспектів загальної проблеми, які суголосні із статтею. В Україні останнім часом видана низка концепцій, у яких визначено основні завдання та мета розвитку освіти дорослих, принципи, форми освіти, напрями реалізації конщепції, передбачено й очікувані результати, піднімається питання обміну досвідом із різними країнами щодо розвитку освіти дорослих; визначено чинники, які впливають на розвиток професійної освіти у ХXI столітті, яка повинна задовольняти потреби держави у кваліфікованих кадрах i потреби особистості в якісній профосвіті.

Формулювання цілей статті (постановка завдання): з'ясуємо зміст концептуальних положень формування освітньої системи дорослих України та яку роль відіграють конщепщії у розвитку освіти дорослих в Україні.

Виклад основного матеріалу дослідження 3 повним обгрунтуванням одержаних наукових результатів. Конщепція “впровадження медіаосвіти в Україні" (2010р.) гарантує забезпечення освіти дорослих медіа ресурсами та інформаційними ресурсами як масивів документів у інформаційних системах 
(банках даних, фондах, архівах тощо), результатом чого має бути медійна та інформаційна грамотність (МіГ) [2], що дозволяє громадянам взаємодіяти 3 медіа та іншими інформаційними службами і розвивати критичне мислення протягом усього життя для спілкування та реалізації активної громадянської позиції [3, c. 15].

У 2002 p. була затверджена колегією МОН України концепція післядипломної освіти, якою було визначено іiі завдання та основні принципи організації післядипломної освіти : гуманізація, демократизація, науковість, диференціація, інтеграція, неперервність. Орієнтація на впровадження модульної системи навчання з урахуванням індивідуального підходу до кожної особистості та впровадження у виробництво нових технологій [4].

3 метою виконання національної стратегії розвитку освіти в Україні на період до 2021 р. було прийнято концепцію розвитку неперервної педагогічної освіти, якою визначено основні принципи розвитку неперервної педагогічної освіти (неперервність, поєднання національних освітніх традицій та найкращого світового досвіду, гнучкість реагування на суспільні зміни і прогностичність, інноваційність), завдання іiі розвитку (вдосконалення структури післядипломної освіти; спрямування розвитку неперервної педагогічної освіти на модернізацію на всіх рівнях освіти змісту, форм, методів та технологій навчання відповідно до вимог інформаційного громадянського полікультурного суспільства); забезпечення якості освіти; запровадження європейського професійно-педагогічного досвіду розвитку неперервної педагогічної освіти. Особлива увага в концепції звертається на післядипломну педагогічну освіту педагогічних працівників, яка здійснюється шляхом: підвищення кваліфікації - в коледжах, академіях, інститутах післядипломної освіти педагогічних працівників і на факультетах (інститутах) педагогічних академій, університетів та класичних університетів; навчання за спеціалізацією педагогічних працівників - у педагогічних коледжах, академіях, університетах і класичних університетах; стажування педагогічних працівників - в університетах, наукових установах національної академії педагогічних наук України, а також в академіях та інститутах післядипломної освіти педагогічних працівників.

Післядипломна педагогічна освіта здійснюється за багатоваріантними освітніми програмами та проектами 3 проблем педагогічної майстерності, інноваційних технологій та інтерактивних форм і методів навчання, інформаційних технологій, досягнень в теорії і практиці психології, педагогіки, методики навчання i виховання, a також за дистанційною формою навчання 3 ефективним використанням інформаційно-комунікаційних технологій [5].

Ми вважаємо, що вихід концепщії розвитку неперервної педагогічної освіти сприяє розвитку освіти дорослих в Україні, адже нею були визначені завдання іiі розвитку, принципи, особлива увага зверталася на існуючу в Україні переважно післядипломну педагогічну освіту, що здійснюється шляхом підвищення кваліфікації багатоваріантними освітніми програмами з проблем педмайстерності.

У 2017 році вийшов методичний посібник "Концепція діяльності центрів освіти “третього віку" в Україні", в якому досліджено теоретичні та прикладні основи діяльності центрів освіти для людей “третього віку” (ЦОТВ) як багатоаспектної складової соціальної політики, системи соціального захисту населення та системи освіти “третього віку” в Україні та за кордоном [6]. 
Важливого значення набув вихід у світ Концепції освіти дорослих в Україні у 2011 році, що розроблена Л. Лук'яновою 3 урахуванням положень Болонської (1999), Лісабонської (2000) і Копенгагенської (2002) декларацій; VI міжнародної конференції з освіти дорослих (“CONFINTEA VI"), Міжнародної ради з освіти дорослих (Дамаск, 2000); Софіївської конференції освіти дорослих (Софія, 2002); Концепції розвитку дорослих у країнах-учасницях співдружності незалежних держав (Москва, 2006); Національної доктрини розвитку освіти (2002) [7, с. 16].

У концепції визначені дефініції, які містять найістотніші ознаки понять: освіта дорослих; дорослість; форми освіти дорослих, визнані ЮНЕСКО (формальна, неформальна, інформальна освіта); технології навчання дорослих; андрагог; ринок праці; соціальне партнерство; визначені принципи освіти дорослих (визнання права на освіту в будь-якому віці; забезпечення освітніх потреб; доступність, неперервність і наступність освіти; партнерство державних органів, недержавних і громадських організацій у забезпеченні розвитку освіти дорослих. Мета концепції освіти дорослих - формування цілісної національної системи освіти дорослих, що охоплює формальну, неформальну та інформальну освіту для задоволення освітніх потреб особистості, що сприяє іiі всебічному розвитку, адаптації до соціально-економічних умов, які змінюються.

Завдання концепції: законодавче унормування механізмів державної підтримки та механізмів фінансування з бюджету, для чого необхідно: прийняти закон України "Про освіту дорослих"; розвивати освіту дорослих з урахуванням потреб ринку праці; розширити доступність освітніх програм для різних груп населення, розробити механізм фінансової підтримки; здійснити у ЗВО підготовку фахівців з освіти дорослих відповідно до потреб ринку, розвивати міжнародну співпрацю в галузі освіти дорослих.

У концепції розроблені напрями реалізації концепції освіти дорослих в галузі:

- правового забезпечення (визнання освіти дорослих на державному рівні, права людини на освіту впродовж життя, доступності освітніх послуг для різних категорій дорослих, розроблення на законодавчому рівні механізмів визнання результатів неформальної та інформальної освіти дорослих);

- управління (забезпечення реалізації стратегії децентралізації в управлінні освітою дорослих - провідну роль надати місцевим органам державної влади та органам місцевого самоврядування, створення місцевих, регіональних i загальнодержавних структур i залучення неурядових організацій i громадських рухів 3 метою розвитку управління якістю і фінансуванням освіти дорослих);

- організаційного та науково-методичного забезпечення (розроблення механізму державного замовлення у ЗВО на підготовку персоналу для роботи 3 дорослими в галузі промисловості, сільському господарстві, підприємництві тощо; забезпечення методичного супроводу освіти дорослих; сприяння розвитку наукових досліджень, орієнтованих на практичну діяльність; вивчення міжнародного досвіду з метою виявлення його прогресивних ідей та визначення перспективних напрямів їх творчого використання в Україні);

- економічного забезпечення (заохочення громадян до навчання впродовж життя, а роботодавців до участі у пролонгованому навчанні працівників; розвиток механізмів фінансування освіти дорослих). 
- У концепції освіти дорослих В Україні передбачені й очікувані результати: створення умов для організації освіти дорослих та подальшої інтеграції України до світового освітнього культурного простору [7, с. 16-22].

Отже, у створеній концепщії освіти дорослих України чітко визначені мета, завдання i напрями реалізації названої концепції, створення умов для організації освіти дорослих та подальшої інтеграції України до світового освітнього культурного простору.

Створення сприятливих умов для мобільності $є$ однією 3 важливих конкурентних переваг у залученні кращих викладачів та дослідників у найбільш прогресивні заклади. Про розв'язання цього питання йдеться в проекті концепції розвитку освіти України на період 2015-2025 років. Особлива увага звертасться на завдання активізації в'їзної викладацької мобільності, яка здатна привнести в українську освітню практику новітні інтерактивні, індивідуалізовані, командні та проектні навчальні технології спільного вироблення нового знання. Сформульовані дуже амбітні індикатори бажаної участі іноземних викладачів у навчальному процесі українських університетів: до 2020 року 15\% освітніх програм повинні мати іноземних викладачів, а до 2025 року їх частка має досягти $30 \%$. Окремо підкреслено пріоритетність залучення мобільних викладачів з країн ЄС та ОЕСР. У концепції зазначено, що реальна позитивна динаміка може бути забезпечена лише після набуття Україною статусу повноправного учасника європейських програм мобільності, на кшталт, "Erasmus+" та “Дії Марії Склодовської-Кюрі” в складі програми "Горизонт 2020".

Автори концепції (Т. Фініков, О. Шаров та ін.) визначили перешкоди i заходи на підтримку мобільності персоналу. До основних груп перешкод виїзної мобільності університетського персоналу в Україні відноситься мовні бар'єри, обмеженість фінансових можливостей, брак навичок швидкого налагодження комунікацій. В'їзна мобільність значною мірою обмежується неспроможністю гарантувати іноземцям звичний для них рівень оплати праці, комфортного проживання та соціального забезпечення, а також незнанням української мови $[8$, c. 127-129].

Як видно із зазначеного, у проекті концепції розвитку освіти України піднімасться важливе питання обміну досвідом щодо розвитку освіти, особливо освіти дорослих, шляхом в'їзної і виїзної викладацької мобільності, але поки що існують бар'єри, які потрібно подолати, зокрема мовний і фінансовий, а також треба набути Україною статус повноправного учасника певних європейських програм мобільності.

Значну роль у розвитку професійної освіти відіграє Концепція розвитку професійно-технічної (професійної) освіти в Україні, мета якої полягає у задоволенні потреб особистості і суспільства у професійних освітніх послугах відповідного рівня з урахуванням вимог ринку праці, забезпечення рівного доступу до якісної первинної професійної освіти, у підготовці, перепідготовці та підвищенні кваліфікації робітників, формуванні творчої особистості. Концепція визначас принципи розвитку професійної освіти: фундаменталізація, диверсифікація, екологізація; індивідуалізація та диференціація професійної освіти; інтеграція професійної освіти, науки і виробництва; випереджувальний характер підготовки кваліфікованого виробничого персоналу; взаємозв'язок процесу професійного навчання 3 реструктуризацією економіки та зайнятості населення, розвитком різних форм власності. 
Концепція також визначає чинники, які впливають на розвиток профосвіти у XXI ст., зокрема: інтелектуалізацію професійної освіти; формування ринку освітніх послуг; особистісно орієнтований підхід у професійному навчанні; модернізацію матеріально-технічного забезпечення професійної освіти на виробництві; надання профоріснтаціїної допомоги різним категоріям населення; розвиток та вдосконалення навчання персоналу на виробництві; обгрунтування критеріїв якісної підготовки, перепідготовки і підвищення кваліфікації робітників.

У концепції розвитку професійної освіти в Україні наголошується на тому, що система професійної освіти повинна задовольняти потреби держави чи регіону в кваліфікованих кадрах і потреби особистості в якісній професійній освіті, зокрема, студентів, що навчаються за технологічним профілем.

Зміст професійної освіти має бути випереджальними, постійно оновлюватися 3 урахуванням динамічних змін у науці, економіці, техніці виробництва та орієнтуватися на нові технології.

Як видно із зазначеного, згідно із концепцією економічні засади розвитку професійної освіти передбачають прогнозування потреб у робітничих кадрах відповідно до вимог ринку праці; впровадження багатоканального фінансування кадрів цієї освіти; формування взаємовідносин ПТНЗ 3 роботодавцями, педагогів із студентами; підготовку конкурентоспроможного професійного фахівця, який відповідає вимогам ринку праці [9, с. 9-13].

Використання концепції відкритого навчання, як зазначає Р. Клопов, підвищує ефективність навчання, дає можливість працювати із значною кількістю дорослих учнів $[10$, с. 37]. На думку С. Змейова, сферу освітніх послуг відкритого навчання характеризує низка специфічних рис, зокрема: різноманітність змісту, форм та методів навчання; свобода вибору тими, хто навчається місця, часу, вартості, рівня, форм, методів навчання i викладачів; сфера освіти дорослих створює послуги, необхідні споживачу; високий ступінь конкуренції між різними видами освітніх послуг; введення освітніх платних послуг [11, с. 28-29].

Навчання і робота нині є синонімами: професійні знання дуже швидко старіють, тому необхідне їх постійне вдосконалення - це і $€$ відкрита освіта. Дистанційне навчання як варіант заочного навчання зародилося на основі сучасних інформаційних технологій [12, с. 235-236; 13].

В Україні Університетом менеджменту освіти НАПН України розроблена модель дистанційного навчання дорослих за заочною формою. Послідовників багато, але це має лише локальний характер, оскільки не всі заклади вищої освіти України мають певне технічне обладнання для використання й адміністрування цих програм [14].

Висновки представленого у статті дослідження і перспективи подальших наукових розвідок із зазначеного напряму. Актуальним питанням про необхідність вчитися впродовж усього життя зробило те, що ні загальноосвітня, ні вища школа не здатні наділити людину знаннями раз і назавжди. Освіту дорослих почали розглядати як систему, покликану компенсувати недоліки загальноосвітньої і вищої школи [1, с. 48].

3'ясовано зміст концептуальних положень формування освітньої системи дорослих України, наголошено на ролі, яку відіграють концепції у розвитку освіти дорослих в Україні.

Як видно із опрацьованого матеріалу, що подано у статті, в Україні хоч $\mathrm{i}$ розроблена модель дистанційного навчання дорослих, але вона має локальний 
характер, бо не всі ЗВО мають відповідне технічне обладнання. Тому над розв'язанням цього питання в системі ОД в Україні потрібно працювати, вивчаючи досвід передових країн світу, на що буде спрямована наша подальша робота.

\section{Література}

1. Архипова С. П. Освіта соціально незахищених категорій дорослих: теорія, методологія, практика: монографія / С. П. Архипова. - Черкаси: ПП Чабаненко, 2011. - 368 с.

2. Концепція впровадження медіа-освіти в Україні. Схвалено постановою Президії Національної академії педагогічних наук України 20 травня 2010 року, протокол № 1-7/6$150 \mathrm{https}: / /$ ru.calameo.com/books/00198748896c858cae696

3. Педагогические аспекты формирования медийной и информационной грамотности М.: Институт ЮНЕСКО по информационным технологиям в образовании (ИИТО), 2012. - 142 с.

4. Освіта дорослих: енциклопедичний словник / за ред. В. Г. Кременя, Ю. В. Ковбасюка; [упоряд.: Н. Г. Протасова, Ю. О. Молчанова, Т.В. Куренна; ред. рада: В. Г. Кремень, Ю.В. Ковбасюк, Н.Г. Протасова та ін.]; Нац. акад. пед. наук України, Нац. акад. держ. упр. при Президентові України [та ін.]. - К. : Основа, 2014. - 496 с. - С. 80.

5. Наказ Міністерства № 1176 від 14.08.2013 “Про затвердження галузевої Концепції розвитку неперервної педагогічної освіти" http://vnz.org.ua/dokumenty/spysok/4487-nakaz-ministerstva1176-vid-14082013

6. Концепція діяльності центрів освіти третього віку в Україні [Текст] : [метод. посіб.] / [авт.уклад.: А. Ю. Горбовий та ін; під заг. ред.: Д. П. Спулбер, А. Ю. Горбовий, А. А. Халецька] ; ДВНЗ “Київ. нац. екон. ун-т ім. Вадима Гетьмана", Укр. ін-т розвитку фонд. ринку. - Київ : УІРФР, 2017. - $115 \mathrm{c}$.

7. Концепція освіти дорослих в Україні/ укл.: Л. Б. Лук'янова. - Ніжин: П П Лисенко М. М., 2011. $-24 \mathrm{c}$.

8. Фініков Т.В., Шаров О.І., Щепетильникова С.С., Смирнов О.О., Лотарєв А.Г., Мобільність науково-педагогічного персоналу // Моніторинг інтеграції української системи вищої освіти в Європейський простір вищої освіти та наукового дослідження: моніторинг. дослідж. : аналіт. звіт / Міжнарод. благод. Фонд "Міжнарод. Фонд дослідж. освіт. політики" ; за заг. ред. Т.В.Фінікова, О.І.Шарова- К. : Таксон, 2014. - С. 127-129.

9. Концепція впровадження медіа-освіти в Україні. Схвалено постановою Президії Національної академії педагогічних наук України 20 травня 2010 року, протокол № 1-7/6$150 \mathrm{https}: / /$ ru.calameo.com/books/00198748896c858cae696

10. Клопов Р. В. Генезис дистанційного навчання / Р. В. Клопов // Педагогічний процес: теорія і практика. - К., 2005. - Вип. 2. - С. 37 - 46.

11. Змеев С.И. Андрагогика: основы теории, истории и технологии обучения взрослых. - М.: М.: ПЕР СЭ, 2007. - С. 91. - $272 \mathrm{c}$.

12. Сігаєва Л. Є. Розвиток освіти дорослих в Україні (друга половина XX - початок XX1 ст.): [монографія] / за ред. С. О. Сисосвої. - К.: ЕКМО, 2010.- 420 с.

13. Кучай О. В. Використання мультимедійних технологій у підготовці вчителів початкових класів : навчальний посібник. - Черкаси : видавець Чабаненко Ю. А., 2015. - 52 с.

14. Олійник В.Освіта впродовж життя: як і чого вчити дорослих? // Управління освітою - 2010. № 1 (229). - C 4-7

\section{References}

1. Arkhypova S. P. Osvita sotsialno nezakhyshchenykh katehorii doroslykh: teoriia, metodolohiia, praktyka: monohrafiia / S. P. Arkhypova. - Cherkasy: PP Chabanenko, 2011. - $368 \mathrm{~s}$.

2. Kontseptsiia vprovadzhennia media-osvity v Ukraini. Skhvaleno postanovoiu Prezydii Natsionalnoi akademii pedahohichnykh nauk Ukrainy 20 travnia 2010 roku, protokol № 1-7/6-150 https://ru.calameo.com/books/00198748896c858cae696

3. Pedahohycheskye aspektyi formyrovanyia medyinoi y ynformatsyonnoi hramotnosty M.: Ynstytut YuNESKO po ynformatsyonnyim tekhnolohyiam v obrazovanyy (YYTO), 2012. - $142 \mathrm{~s}$.

4. Osvita doroslykh: entsyklopedychnyi slovnyk / za red. V. H. Kremenia, Yu. V. Kovbasiuka; [uporiad.: N. H. Protasova, Yu. O. Molchanova, T.V. Kurenna; red. rada: V. H. Kremen, Yu.V. Kovbasiuk, N.H. Protasova ta in.]; Nats. akad. ped. nauk Ukrainy, Nats. akad. derzh. upr. pry Prezydentovi Ukrainy [ta in.]. - K. : Osnova, 2014. - 496 s. - S. 80.

5. Nakaz Ministerstva № 1176 vid 14.08.2013 "Pro zatverdzhennia haluzevoi Kontseptsii rozvytku neperervnoi pedahohichnoi osvity" http://vnz.org.ua/dokumenty/spysok/4487-nakaz-ministerstva1176-vid-14082013 
6. Kontseptsiia diialnosti tsentriv osvity tretoho viku v Ukraini [Tekst] : [metod posib.] / [avt. -uklad.: A. Yu. Horbovyi ta in; pid zah. red.: D. P. Spulber, A. Yu. Horbovyi, A. A. Khaletska] ; DVNZ "Kyiv. nats. ekon. un-t im. Vadyma Hetmana", Ukr. in-t rozvytku fond. rynku. - Kyiv : UIRFR, 2017. - $115 \mathrm{~s}$.

7. Kontseptsiia osvity doroslykh v Ukraini/ ukl.: L. B. Lukianova. - Nizhyn: P P Lysenko M. M., 2011. $-24 \mathrm{~s}$.

8. Finikov T.V., Sharov O.I., Shchepetylnykova Ye.Ie., Smyrnov O.O., Lotariev A.H., Mobilnist naukovo-pedahohichnoho personalu // Monitorynh intehratsii ukrainskoi systemy vyshchoi osvity v Yevropeiskyi prostir vyshchoi osvity ta naukovoho doslidzhennia: monitorynh. doslidzh. : analit. zvit / Mizhnarod. blahod. Fond "Mizhnarod. Fond doslidzh. osvit. polityky" ; za zah. red. T.V.Finikova, O.I.Sharova- K. : Takson, 2014. - S. 127-129.

9. Kontseptsiia vprovadzhennia media-osvity v Ukraini. Skhvaleno postanovoiu Prezydii Natsionalnoi akademii pedahohichnykh nauk Ukrainy 20 travnia 2010 roku, protokol № 1-7/6-150 https://ru.calameo.com/books/00198748896c858cae696

10. Klopov R. V. Henezys dystantsiinoho navchannia / R. V. Klopov // Pedahohichnyi protses: teoriia i praktyka. - K., 2005. - Vyp. 2. - S. $37-46$.

11. Zmeev S.Y. Andrahohyka: osnovyi teoryy, ystoryy y tekhnolohyy obuchenyia vzroslyikh. - M.: M.: PER SЭ, 2007. - S. 91. $-272 \mathrm{~s}$.

12. Sihaieva L. Ye. Rozvytok osvity doroslykh v Ukraini (druha polovyna KhKh - pochatok KhKhl st.): [monohrafiia] / za red. S. O. Sysoievoi. - K.: EKMO, 2010.- $420 \mathrm{~s}$.

13. Kuchai $\mathrm{O}$. V. Vykorystannia multymediynykh tekhnolohiy u pidhotovtsi vchyteliv pochatkovykh klasiv : navchalnyy posibnyk. - Cherkasy : vydavets Chabanenko Yu. A., 2015. I 52 s.

14. Oliinyk V.Osvita vprodovzh zhyttia: yak i choho vchyty doroslykh? // Upravlinnia osvitoiu - 2010. № 1 (229). - S 4-7

Одержано статтю: 5.02 .2019

Прийнято до друку: 19.03.2019

УДК 37.012:929:930(045)

DOI:10.15330/esu. $15.45-51$
Ірина Розман,

кандидат педагогічних наук, доцент,

Мукачівський державний університет

(м. Мукачево, Україна)

Iryna Rozman,

Candidate of pedagogical sciences $(\mathrm{PhD})$,

Associate Professor, Mukachevo State University

(Mukachevo, Ukraine)

rozmanii@ukr.net

\section{ПЕДАГОГІЧНА БІОГРАФІСТИКА: ДЖЕРЕЛОЗНАВЧИЙ АСПЕКТ}

\section{PEDAGOGICAL SCIENCE OF BIOGRAPHY: SOURCE-STUDY ASPECT}

У статті розглянуто проблему чіткого розмежування понять “автентичне периоджерело” (як “джерело-факт”, “джерело-подія”) та “історіографічне джерело” як різновид науково-аналітичних студій. Обтрунтовано думку щодо необхідності класифікачій історико-педагогічних джерел вивчення біографістики. Констатовано, ио, коли дослідник визначас типову структуру джерельної бази історико-педагогічного досліджения, відбувається виокремлення в ній трьох основних груп матеріалів. Зазначено, ще міждисчиплінарність біографістики зумовлюе потребу використання науковометодологічного інструментарію не лиие історико-педагогічної науки (яка спирається на досвід історичної науки), а й іниих галузей знань: психології, сочіології, лінгвістики, історії.

Ключові слова: джерелознавча проблема, досліджения, класифікачія, історикопедагогічний прочес. 